\title{
PENTINGNYA PENDIDIKAN KARAKTER PADA ANAK USIA DINI
}

\author{
Herlina \\ Email : 2010128320002@mhs.ulm.ac.id \\ Program Studi Pendidikan IPS Fakultas Keguruan dan Ilmu Pendidikan \\ Universitas Lambung Mangkurat \\ Banjarmasin
}

\begin{abstract}
Abstrak
Pendidikan adalah suatu usaha untuk mengubah sebuah perilaku atau tingkah laku yang dimilki seseorang melalui suatu pengajaran atau bimbingan. Sedangkan Karakter adalah suatu sikap, perilaku, atau watak yang dimiliki oleh seseorang yang menjadi kebiasaan. Usia Dini adalah usia yang berusia di bawah tujuh tahun, usia tersebut adalah usia yang tepat untuk membentuk karakter anak karena usia tersebut belum terpengaruh dari berbagai pengaruh negatif dari luar atau tempat tinggalnya. Dalam pembentukan karakter anak Peran Orang tua atau keluarga terhadap pengembangan karakter anak sangat berpengaruh, karena kelurgalah yang pertama dikenal oleh anak, sehingga anak akan mudah meniru perilaku kelurga anak tersebut, kemudian guru juga sangat berperan terhadap pendidikan karakter anak karena selain memberikan ilmu pengetahuan guru juga dituntut untuk mendidik. Oleh karena itu keluarga maupun guru sama-sama berperan penting terhadap pengembangan karakter anak. Pengembangan karakter anak dapat dimulai dari cara yang sederhana sehingga karakter anak tersebut menjadi kebiasaan dalam hidupnya. Pendidikan Karakter pada Anak Usia Dini bertujuan untuk membentuk watak ataupun akhlak mulia anak menjadi kebiasaan yang lebih baik sehingga menjadi masa depan yang baik pula.
\end{abstract}

\section{PENDAHULUAN}

Manusia tidak terlepas oleh dunia pendidikan, di dalam keluarga, masyarakat, maupun sekolah terdapat suatu pendidikan. Pendidikan dalam keluarga merupakan pendidikan pertama yang ditemukan oleh anak sejak ia dilahirkan seperti penanaman nilai, etika, moral, maupun akhlaknya. Pendidikan yang didapat oleh anak tersebut dapat membentuk karakter suatu anak. Setelah anak sudah mengenal lingkungan masyarakat maka dia akan mendapatkan pendidikan yang bersifat sosial yang mana dapat mengajarkan anak tersebut bagaimana bersosialisasi atau berinteraksi dengan orang lain. Selain keluarga dan masyarakat, ketika anak sudah memasuki usia sekolah maka ia akan mendapatkan pendidikan formal di sekolah yang berkaitan dengan akademik dan juga terdapat pendidikan karakter didalamanya. Adapun yang dimaksud dengan pendidikan karaktrer adalah pendidikan yang mengajarkan tentang tabiat, 
kepribadian, sikap maupun akhlaknya sehingga suatu individu dapat mewujudkan suatu yang diharapkan. Artinya suatu lembaga pendidikan diharapkan dapat mengedepankan penanaman dan pengembangan nilai-nilai karakter pada peserta didik dalam proses pembelajaran yang kemudian dapat diterapkan dalam kehidupan sehari-hari. Pendidikan karakter pada anak usia dini merupakan suatu proses permulaan yang tepat karena di usia inilah anak mengalami suatu periode perkembangan yang sangat penting dalam kehidupan manusia agar kedepannya menjadi lebih baik, pertumbuhan dan perkembangan anak diusia ini berlangsung dengan cepat dan akan menjadi penentu bagi karakter anak dimasa depan. Pendidikan karakter yang dimulai dari usia dini diharapkan dapat menjadi para gemerasi penerus bangsa yang memiliki karakter atau sikap yang baik. Selain itu juga penanaman karakter di usia dini merupakan masa persiapan untuk sekolah pada tingkat selanjutnya, maka hal tersebut sangat baik dilakukan agar mendapat apa yang diharapkan.

\section{METODE PENELITIAN}

Dalam Penelitian ini menggunakan pendekatan kualitatif deskriftif. Penelitian Kualitatif bersifat deskriftif yaitu beruapa penjelasan dari berbagai sumber-sumber ilmiah atgau jurnal-jurnal ilmiah yang di dapat oleh peneliti. Penelitian Kualitatif yang bersifat deskriptif mengarah pada pendiskripsian secara rinci dan mendalam baik kondisi maupun proses, dan juga saling berkaitan mengenai hal-hal pokok yang ditemukan oleh peneliti. (Sutopo, 2006:179).

\section{PEMBAHASAN}

Pendidikan merupakan suatu proses perubahan sikap atau tingkah laku melalui suatu pengajaran atau bimbingan sehingga menjadikan individu menjadi lebih baik. Sedangkan karakter berasal dari bahasa yunani "charassien" yang berarti memahat. Menurut Suryanto (Wibowo, 2012) karakter diartikan sebagai cara berpikir dan berperilaku yang menjadi ciri khas individu untuk hidup bersama dalam lingkup keluarga, masyarakat, bangsa dan negara. Jadi Pendidikan Karakter adalah suatu usaha untuk menanamkan dan mengembangkan nilai-nilai karakter suatu bangsa kepada anak didik, sehingga dapat diterapkan di lingkungan keluarga, masyarakat ataupun sekolah.

Pendidikan Karakter suatu hal yang penting diberikan kepada anak didik karena 
berhubungan dengan perilaku, sikap, perbuatan dan lain-lain yang berdasarkan pada norma-norma agama, hukum, budaya dan adat istiadat yang nantinya dapat di terapkan dikehidupan sehari-hari. Pendidikan Karakter adalah pendidikan yang memiliki 3 aspek yaitu Pengetahuan, Perasaan, dan tindakan. Dengan tiga aspek tersebut maka pendidikan karakter akan berjalan dengan efektif, dari pendidikan tersebut maka anak akan memiliki perilaku yang baik untuk diterapkan dalam kehidupan sehari-hari. Pendidikan Karakter pada Anak Usia Dini adalah pendidikan yang diberikan kepada anak yang berusia dibawah tujuh tahun, yang mana usia tersebut anak memerlukan suatu bimbingan, anak lahir ke dunia dengan membawa segenap potensi yang diberikan oleh Maha Kuasa, dengan itu anak perlu bimbingan untuk mengembangkan potensi tersebut. Pendidikan Karakter yang dimulai dari usia dini sangat berperan penting dan berpengaruh dalam mengembangkan karakter seorang anak, pendidikan ini berpengaruh terhadap masa depannya, misalnya saja keberhasilan seseorang di masa depan dapat dipengaruhi oleh masa kecilnya. Jadi Pendidikan Karakakter adalah suatu pendidikan yang penting agar kedepannnya menjadi lebih baik.

Tujuan dari Pendidikan Karakter pada Anak Usia Dini menurut Muslich (2011) adalah untuk meningkatkan mutu dalam pembelejarannya dan hasil pendidikan yang mengarah pada tercapainya pembentukan karakter dan akhlak peserta didik secara terpadu, utuh dan seimbang. Sedangkan menurut Rahmawati (2017) pendidikan karakter bertujuan mengembangkan suatu nilai yang membentuk karakter bangsa yaitu Pancasila yang meliputi, 1) Menumbuhkan potensi peserta didik agar menjadi manusia berhati mulia, berpikir, dan berperilaku baik, 2) Menciptakan Bangsa berkarakter Pancasila, 3) Mengembangka sebuah potensi yang dimilki peserta didik agar memilki sikap percaya diri, berbangsa dan bernegara. Oleh karena itu dapat disimpulkan bahwa tujuan dari Pendidikan Karakter adalah untuk membentuk suatu sikap, perilaku, atau tingkah laku yang dimiliki oleh seseorang atau anak didik melalui suatu pengajaran atau bimbingan yang nantinya diharapkan akan menjadi lebih baik dan siap akan masa depan anak didik tersebut dan perilaku yang baik tersebut akan menjadi terbiasa dalam hidupnya sehingga akan menciptakan suatu hal yang diharapakan.

Pembentukan Karakter Anak dapat dimulai dari ruang lingkup keluarga, karena hal pertama yang ditiru oleh anak adalah keluarga. Pendidikan Karakter ini sebaiknya 
diterapkan sejak anak usia dini atau anak yang berusia dibawah tujuh tahun, karena masa ini adalah masa yang sangat menentukan kemampuan anak dalam mengembangkan suatu potensi yang ada dalam dirinya. Namun peran lembaga pendidikan yaitu guru juga tidak lepas dari pembentukan karakter anak didik. peran guru sangat penting dalam pembentukan karakter anak karena tugas guru tidak hanya memberi ilmu tetapi juga mendidik. Tugas guru yaitu membantu anak dalam mendapatkan ilmu penegetahuan yang dapat bermanfaat bagi anak dan juga memilki karakter dan kepribadian yang baik yaitu sesuai dengan tujuan pendidikan yaitu mengembangkan potensi peserta didik untuk memiliki kecerdasan, kepribdian dan akhlak mulia (Undang-undang Sisdiknas tahun 2003). Pengembangan Karakter anak ini dapat dilakukan dengan cara melakukan pembiasaan dan melalui kegiatan inti. Melakukan pembiasaan contohnya seperti Cuci tangan dan berdoa sebelum dan sesudah makan, berdoa sebelum tidur, membersihkan lingkungan dan lain sebagainya. sedangkan pengenalan melalui kegiatan inti contohnya seperti memeriahkan "Hari Pahlawan" yang bertujuan untuk mengembangkan sifat kefahlawanan anak-anak. Dengan demikiian mulai dari cara yang sederhana tersebut dapat mengembangkan karakter pada diri anak-anak.

Dengan adanya Pendidikan Karakter di Usia Dini maka anak akan lebih siap dalam menghadapi masa depan yang penuh dengan tantangan baik di bidang akademik maupun berbangsa dan bernegara. Dengan adanya suatu perubahan sosial yang terjadi dalam masyarakat yang menghasilkan penemuan baru seperti Handphone maupun Televisi, hal tersebut juga dapat mempengaruhi kehidupan anak usia dini. Oleh karena itu terdapat Dampak Positif dan Negatif bagi anak usia dini. Dampak Negatif nya yaitu anak akan menjadi candu terhadap Handphone yang digunakannya sehingga akan malas dalam belajar, anak-anak juga terkadang menonton acara televisi yang mungkin tidak mendidik, sehingga tidak baik untuk masa yang akan datang. Sedangkan Dampak Positif nya yaitu anak akan menjadi mudah dalam berkomunikasi atau berinteraksi serta dengan handphone anak bisa melihat atau menonton animasi di internet sehingga ia mendapatkan pengetahuan seperti cara menggambar. Dengan melihat fenomena di atas sudah seharusnya para pendidik baik guru maupun orang tua mengembangkan pendidikan karakter mulai dari usia dini agar nantinya memiliki akhlak mulia atau 
karakter yang baik, budi pekerti yang baik dengan mengurangi dampak negatif dari perkembangan zaman dan kemajuan teknologi.

\section{SIMPULAN}

Pendidikan Karakter Anak Usia Dini merupakan pendidikan yang memberikan suatu pengetahuan akan nilai-nilai karakter kepada anak didik, sehingga mereka akan memiliki karakter yang baik untuk diterapkan di kehidupan sehri-hari maupun dalam berbangsa dan bernegara. Pendidikan ini perlu dilaksanakan sejak anak usia dini, anak usia dini adalah anak yang berumur dibawah tujuh tahun, pada usia tersebut sangat tepat untuk diberikan pendidikan karakter karena usia tersebut anak belum memiliki pengaruh negatif yang banyak dari luar atau dilingkungan tempat tinggalnya. Pendidikan Karakter ini bertujuan agar kedepannya anak sudah siap akan masa depan dan tentunya memiliki karakter yang baik sehingga dapat diterapkan di kehidupan sehari-hari, selain itu juga bertujuan untuk membentuk jiwa anak agar memiliki jiwa kebangsaan,dan dapat memanimalisir anak dari pengaruh negatif dari luar. Peran Orang tua atau keluarga terhadap pengembangan karakter anak sangat berpengaruh, karena keluarga lah yang pertama dikenal oleh anak, sehingga anak akan mudah meniru perilaku kelurga anak tersebut, kemudian guru juga sangat berperan terhadap pendidikan karakter anak karena selain memberikan ilmu pengetahuan guru juga dituntut untuk mendidik. Pengembangan Karakter anak ini dapat dilakukan dengan cara melakukan pembiasaan dan melalui kegiatan inti. Melakukan pembiasaan contohnya seperti Cuci tangan dan berdoa sebelum dan sesudah makan, berdoa sebelum tidur, membersihkan lingkungan dan lain sebagainya. sedangkan pengenalan melalui kegiatan inti contohnya seperti memeriahkan "Hari Pahlawan" yang bertujuan untuk mengembangkan sifat kefahlawanan anak-anak. Dengan demikiian mulai dari cara yang sederhana tersebut dapat mengembangkan karakter pada diri anak-anak. Pendidikan Karakter pada Anak Usia Dini dapat dikatakan berhasil apabila anak sudah mengalami perubahan perilaku atau anak sudah mampu memberikan sikap atau akhlak mulia yang baik. 


\section{DAFTAR PUSTAKA}

Putra, M. A. H. (2019). Building Character Education Through The Civilization Nations Children. The Kalimantan Social Studies Journal, 1(1), 12-17.

Suyanto, S. (2012). Pendidikan Karakter Untuk Anak Usia Dini. Jurnal Pendidikan Anak, 1 (1).

Hadisi, L. (2015). Pendidikan Karakter Pada Anak Usia Dini. AL-TA'DIB: Jurnal Kajian Ilmu Kependidikan, 8(2), 50-69.

Cahyaningrum, Eka Sapti; Surdayanti, Surdayanti; Purwanto, Nurtanio Agus. Pengembangan nilai-nilai Karakter anak usia dini melalui pembiasaan dan keteladanan. Jurnal Pendidikan Anak. 2017, 6.2: 203-213.

Khaironi, M (2017). Pendidikan Karakter anak usia dini. Jurnal Golden Age, 1 (02), 8289.

Iswantiningtyas, V, \& Wulansari, W. (2018). Pentingnya penilaian pendidikan karakter anak usia dini. Proceedings of the ICECRS, 1(3).

Nuraeni, N. (2020). Pendidikan Karakter Pada Anak Usia Dini. Jurnal Paedagogy, 3(2), $65-73$ 